\title{
Initialism as a Mechanism of Weed Interference: Can a Crop Plant Be Blinded? ${ }^{1}$
}

\author{
Inicialismo como um Mecanismo de Interferência das Plantas Daninhas: Pode uma Cultura Ser \\ Cega?
}

\author{
VIDAL, R.A. ${ }^{2}$, TREZZI, M.M. ${ }^{3}$, KOZLOWSKI, L.A. ${ }^{4}$, PRATES, M.V.B. ${ }^{3}$, CIESLIK, L.F. ${ }^{3}$ and \\ MEROTTO JR., A. ${ }^{2}$
}

\begin{abstract}
Initialism is a new word proposed to indicate the "shade-avoidance syndrome". Plants detect the presence of neighbor plants very early in the growing season through changes in light quality. They modify the allocation of photosynthesis products privileging shoot growth over the roots. One of the hypotheses of the authors is that, when weed management is timely scheduled, a "blind" crop could be more productive because it would avoid an imbalance on the shoot:root ratio (S:R). Two strategies were developed to test this hypothesis: a) to use the classical Yoda's Law to screen several crops for insensitivity to S:R imbalance; b) to evaluate several growth regulators to control the plant responses to crowding. Experimental results confirm that both strategies can yield insensitive plants. The possibilities of the use of this knowledge are discussed.
\end{abstract}

Keywords: initialism, shade-avoidance syndrome, genetic, growth regulator.

RESUMO - Inicialismo é uma palavra nova proposta para indicar a "sindrome de escape ao sombreamento". Plantas detectam a presença de outras plantas vizinhas muito cedo no seu ciclo de crescimento por meio das mudanças na qualidade da luz. Elas modificam a alocação de produtos da fotossintese, privilegiando o crescimento de ramos sobre as raizes. Uma das hipóteses dos autores é que, quando o manejo de plantas daninhas é programado para ser realizado em pós-emergência, uma cultura "cega" poderia ser mais produtiva, porque se evitaria um desequilíbrio nas proporções entre parte aérea e raiz (PA:R). Duas estratégias foram desenvolvidas para testar essa hipótese: a) usar a lei de Yoda clássica para averiguar a insensibilidade de diversas culturas ao desequilíbrio PA:R; e b) avaliar vários reguladores de crescimento para controlar as respostas das plantas ao adensamento. Os resultados experimentais confirmam que ambas as estratégias podem produzir plantas insensiveis ao inicialismo. Neste estudo são discutidas as possibilidades de utilização desse conhecimento.

Palavras-chave: inicialismo, síndrome de escape ao sombreamento, genética, regulador de crescimento.

\section{INTRODUCTION}

Plants have the ability to detect the quality of light intercepted and are subjected to photomorphogenesis. The phytochrome detects wavelengths between the red (R) and far red (FR). The presence of neighboring plants decreases the ratio of R:FR, signaling prematurely to seedlings that there will be competition in the future and thereby alters the plant form. Currently, this phenomenon is called 'shade avoidance syndrome'. However, the authors have proposed that the term INITIALISM is more appropriate than the former as a scientific name to express the first process (process) of plant-plant interaction (Vidal et al., 2008).

1 Recebido para publicação em 17.5.2012 e aprovado em 17.7.2012.

2 Universidade Federal do Rio Grande do Sul-UFRGS, Porto Alegre-RS, Brazil, <ribas.vidal@gmail.com>; ${ }^{3}$ Universidade Tecnológica Federal do Paraná, Pato Branco-PR, Brazil; ${ }^{4}$ Pontifiícia Universidade Católica - PUC, Curitiba, PR, Brazil. 
At least three reasons justify the use of the term INITIALISM. First, the types of plant-plant interactions were classified by Burkholder (1952) as neutral (neutralism), or positive (mutualism, commensalism, protocooperation, and two types left unnamed), or negative (parasitism, amensalism, competition, and one type left unnamed). Vidal et al. (2008) proposed INITIALISM as the term appropriate to describe the unnamed term for negative interaction that is characterized by a negative effect on one species and a positive (or neutral) effect on the other species when the two are living together; and a neutral effect for each species when both are living apart. The second reason is that INITIALISM has a Latin (language) root, such as 'initialis' meaning 'in the beginning' and 'ism' meaning 'with reference to'. The neutral origin of the name, based on the Latin language, is more appropriate to express scientific ideas. Furthermore, this Latin origin for the word gives it a universal nomenclature and follows the trend of most of the other terms proposed in plant ecology to explain plant-plant interaction (Burkholder, 1952; Vidal et al., 2008). Finally, the major problem with the term 'shade avoidance syndrome' is that it is misleading. This term suggests the amount of light is involved in the process. However, nowadays science has elucidated part of the steps involved in the phenomena, and it includes the light quality (R:FR balance), a cascade of signaling events (phytochrome conversion; production of the proteins DELLA and PIF, among others; gibberellin synthesis and action; involvement of auxin; and plant response) (Achard et al., 2007; DjakovicPetrovic et al., 2007; Franklin, 2008; Ballare, 2009).

The fact is that R:FR proportion detected early by the plants affects its morphology. Thus, during the beginning of the life cycle and under high R:FR (no weeds), the crop plants invest a high proportion of photoassimilates to root development. However, under low R:FR (weedy conditions) the crop plant prioritizes the development of shoots over roots in order to become more competitive for light resources (Rajcan \& Swanton, 2001; GreenTracewicz et al., 2012). Theoretically, biomass investment in stem elongation increases a species competitively for light, but, in situations of weed control with herbicides applied postemergence, the photomorphogenesis change is a nonsense investment and the lack of a well developed root system may alter the crop tolerance to water stress with a negative impact on the crop yield potential (Maliakal et al., 1999; Vidal et al., 2008).

One hypothesis proposed by the authors is that 'blind' crops, i.e. insensitive to changes in light quality, would be the least affected by the initial interaction of weeds and, under postemergence weed control, would have a high yield potential. It would be possible to attain 'blind' crop plants by three processes. First, transgenic manipulation of the genes involved either on the light quality sensors (Boccalandro et al., 2003), or on the cascade of events that lead to the phenotypic modifications. Second, through the selection of genotypes insensitive to light quality. Third, with the use of plant growth regulators.

We speculate that in the family Fabaceae there is a high probability to find genetic variability for this trait due to the fact that this group of plants has had limited human intervention throughout its evolution. Another proposal of this work is that growth regulators could be used to 'blind' the crop. Part of the signaling events involved in the INITIALISM process was already elucidated and they involve gibberellins (Achard et al., 2007; Djakovic-Petrovic et al., 2007; Franklin, 2008; Ballare, 2009). In addition, auxins seem to be involved in the apical dominance under crowding conditions for grass plants (Almeida $\&$ Mundstock, 2001). Several plant growth regulators belonging to different groups of mechanisms of action are currently in agricultural use, including: inhibitors of auxin synthesis (2, 3, 5-triiodobenzoic acid - TIBA), inhibitors of gibberellin synthesis (trinexapac ethyl chloride - Moddus, and mepiquat chloride - Pix), ethylene precursor (etephon - Ethrel) and a plant growth stimulator (IBA + kinetin + GA3 - Stimulate).

The objectives of this paper were to evaluate whether plant density affect its morphology, to search for genotypes insensitive to the change in density among different Fabaceae species, and to check whether bean (Phaseolus vulgaris) plants and other crop model species have their morphology affected by 
growth regulators to reduce the initialism effect in plants.

\section{MATERIAL AND METHODS}

Two groups of experiments were conducted under semi-controlled conditions. In the field, five other experiments were conducted to further test the proposed hypothesis. The studies are described separated, according to the major objectives.

\section{Screening of crop species}

The first group of experiments was conducted in the Laboratory of Ruderal Flora (LAFLOR), School of Agronomy, UFRGS, located in Porto Alegre, RS, Brazil. Treatments were arranged in a $6 \times 5$ factorial, where to factor A the Fabaceae species (azuki bean (Vigna angularis), pea (Pisum sativum), brown and common beans (Phaseolus vulgaris), cowpea (Vigna unguiculata) and lentil (Lens culinaris)) were assigned, and to Factor B the plant densities per pot (ranging between 1 and 22 plants) were assigned.

The seeds of these species were placed in pots with a capacity of $500 \mathrm{~g}$ containing as substrate a mixture of soil: compost $(3: 1, \mathrm{v}: \mathrm{v})$. Irrigation was performed by capillary action, keeping a plastic tray with water under the pots. The seeds were sown twice and the desired plant density and four days after seedlings emergence (DAE) the plants were thinned according to the treatment. The experiment was repeated three times.

At $21 \mathrm{DAE}$, the plant mass was evaluated. For this assessment, roots (R) were separated from shoot (S), and their masses were determined after the dehydration of the tissue in an oven maintained at a temperature of $60{ }^{\circ} \mathrm{C}$. The data of $\mathrm{S}, \mathrm{R}$, and $\mathrm{S}+\mathrm{R}$ mass per plant, and the ratio of total S:R mass were submitted to the analysis of variance. When the interaction was significant, regressions were performed between density and S:R mass/ plant and between density and total mass.

\section{Studies with growth regulators}

The experiment was conducted in the plastic greenhouse at the Agronomy School,
UTFPR, located in Pato Branco, PR, Brazil. The experimental design was randomized blocks with five replicates. The treatments were arranged in a factorial model, where to Factor A was assigned plant density per pot (two and eight) and to Factor B it was assigned the six treatments with growth regulators [T1: untreated, T2: Tiba (2,3,5-triiodobenzoic acid), T3: Ethrel (etephon), T4: Pix (mepiquat chloride), T5: Stimulate (3-indolebutyric acid (IBA) + kinetin + giberellic acid (GA3)), and T6: Moddus (trinexapac ethyl)].

Pots with a capacity of $1,000 \mathrm{~mL}$, containing the same substrate to the previously described were used to place the common bean seeds (P. vulgaris). The seeds were placed at $4 \mathrm{~cm}$ depth, spaced evenly in a density per pot twice as higher than that required by the treatment. One DAE, the desired density per pot was attained after thinning excess plants. All treatments were watered daily as described previously.

The emergence of the plants occurred five days after sowing. Five DAE the growth regulators were applied in the following doses in (g a.i. ha ${ }^{-1}$ ) T2: 8; T3: 108; T4: 50; T5: 0.025 $+0.025+0.045$; and T6: 125 . The products were applied with a backpack sprayer pressurized with $\mathrm{CO}_{2}$, delivering a water volume of $160 \mathrm{~L} \mathrm{ha}^{-1}$.

The evaluations were conducted 14 days after treatment (DAT). The plant (shoot) height, and $\mathrm{S}$ and $\mathrm{R}$ mass after dehydration at a constant temperature of $60^{\circ} \mathrm{C}$, were evaluated. The data were subjected to analysis of variance and when significance was found by the $\mathrm{F}$ test, the comparison of treatment means was conducted using the Scott-Knott test at $5 \%$ probability of experimental error.

\section{Field experiments}

Five field experiments were conducted on the Experimental Stations of the UFRGS, located in Eldorado do Sul, RS, and of Pontifice Catholic University (PUC), located in Curitiba, PR; and on a farm located in Realeza, PR. The experimental design was randomized blocks with six, four, and six replicates, respectively.

In November-December 2011, the seeds of the following crops/locations were seeded 
using tractorized equipment: common bean seeds ( $P$. vulgaris) (Eldorado do Sul and Curitiba); soybean (Glycine max) (Curitiba and Realeza); corn (Zea mays) (Curitiba). Planting conditions followed current farming density and spacing. The treatments consisted of the crop plants treated or untreated with the growth regulator trinexapac ethyl (125 $\mathrm{g} \mathrm{ha}^{-1}$ ) on the experiments located at Curitiba and Realeza, and mepiquat chloride $\left(50 \mathrm{~g} \mathrm{ha}^{-1}\right)$ on Eldorado do Sul experiment. About five days after the crop seedling emergence the growth regulators were sprayed using equipment and the conditions described previously.

The shoot and root of at least 16 crop plants were sampled 10 DAT and their mass was evaluated after dehydration at a constant temperature of $60{ }^{\circ} \mathrm{C}$. The means for the proportion of S:R mass and its standard error were used for comparisons.

\section{RESULTS AND DISCUSSION}

\section{Selection of genotypes}

The total mass per plant depended on the density and of the species evaluated. With increasing plant density per pot the total individual mass was reduced for brown beans, common beans and cowpea (Figure 1). For these tree species, the asymptotes for the power curves were very similar and reached the approximate value of $0.2 \mathrm{~g}$ per plant (Figure 1). The regression between density and individual mass has not confirmed adjustment to the power equation for the species azuki, lentil, and peas (Table 1).

Currently, there is no mechanistic theory to explain the relationship between density and SM:RM. Thus, we chose to test various mathematical models of fit of the data and the simplest model which showed the lowest sum of squared of the residues between the adjusted data and the observed was the linear equation (Table 1). Linear equations were set for the relationship between density and SM:RM for all the genotypes tested, regardless of the degree of significance found (Table 1). Among all genotypes, only a significant regression $(\mathrm{P}<0.05)$ for the azuki beans was detected. It was found that with the increase of azuki density per pot, the ratio SM:RM decreased by 0.19 units (Table 1 ). There was no significant regression between density and SM:RM for the other genotypes, but two major differences can be observed in the results: declivity of the curve and regression coefficient. Cowpea and peas had the smaller declivities and common beans and peas had the smallest regression coefficient (Table 1).

\section{Studies with growth regulators}

The plant height was affected by the density factor in all treatments with growth regulators (Table 2). Plants in treatments under high density ( 8 plants per pot) had

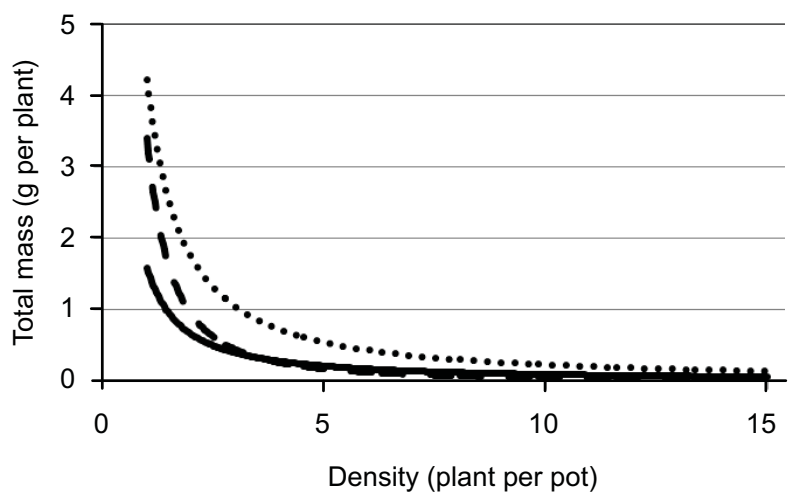

Figure 1 - Relationship between plant density and individual mass (g per plant) for three genotypes adjusted to the power law. (dotted line = brown bean; dashed line = cowpea; solid line $=$ common bean). Porto Alegre, Brazil.

Table 1 - Adjustment coefficient for the power equation $\left(\mathrm{R}^{2}\right)$ between density and total individual mass and the regressions between the density and the ratio between shoot mass and root mass (SM:RM) for six leguminous species, evaluated at 21 days after emergence. Porto Alegre, Brazil

\begin{tabular}{|c|c|c|c|}
\hline \multirow[t]{2}{*}{ Plant species } & \multirow{2}{*}{$\begin{array}{c}\mathrm{R}^{2} \text { for the } \\
\text { power } \\
\text { equation }\end{array}$} & \multicolumn{2}{|c|}{$\begin{array}{c}\text { Regression between density and } \\
\text { SM:RM }\end{array}$} \\
\hline & & Equation & 2 \\
\hline Azuki beans & $0.61 \mathrm{~ns}$ & $Y=7.5-0.19 x$ & $0.80 *$ \\
\hline Brown beans & $0.83 * *$ & $\mathrm{Y}=6.1-0.14 \mathrm{x}$ & $0.25 \mathrm{~ns}$ \\
\hline Common beans & $0.89 * *$ & $\mathrm{Y}=8.1-0.10 \mathrm{x}$ & $0.02 \mathrm{~ns}$ \\
\hline Cowpea & $0.90 * *$ & $\mathrm{Y}=4.2+0.03 \mathrm{x}$ & $0.22 \mathrm{~ns}$ \\
\hline Lentils & $0.02 \mathrm{~ns}$ & $\mathrm{Y}=3.8+0.10 \mathrm{x}$ & $0.27 \mathrm{~ns}$ \\
\hline Peas & $0.12 \mathrm{~ns}$ & $\mathrm{Y}=2.6-0.01 \mathrm{x}$ & $0.06 \mathrm{~ns}$ \\
\hline
\end{tabular}

ns $=$ non significant $(\mathrm{P}>0.05) ; *$ and $* *=$ significant $(\mathrm{P}<0.05$ and $\mathrm{P}<0.01$, respectively). 
Table 2 - Height (cm) of bean plants at 14 days after the treatment with growth regulators. Pato Branco, Brazil

\begin{tabular}{|c|c|c|c|c|c|c|}
\hline Density & Untreated & Tiba $^{1 /}$ & Ethrel & Stimulate & Moddus & Pix \\
\hline 2 plant per pot & $16.9 \mathrm{bB}^{2 /}$ & $17.0 \mathrm{bB}$ & $17.1 \mathrm{bB}$ & $20.3 \mathrm{bA}$ & $14.1 \mathrm{bC}$ & $13.8 \mathrm{bC}$ \\
\hline 8 plant per pot & $19.8 \mathrm{aB}$ & $19.6 \mathrm{aB}$ & $20.2 \mathrm{aB}$ & $23.4 \mathrm{aA}$ & $15.2 \mathrm{aC}$ & $15.2 \mathrm{aC}$ \\
\hline
\end{tabular}

1/ Tiba = 2,3,5-triiodobenzoic acid $\left(8 \mathrm{~g} \mathrm{ha}^{-1}\right)$; Ethrel = etephon $\left(108 \mathrm{~g} \mathrm{ha}^{-1}\right)$; Pix $=$ mepiquat chloride $\left(50 \mathrm{~g} \mathrm{ha}^{-1}\right)$; Stimulate $=3$-indolebutyric acid + kinetin + giberellic acid $\left(0.025+0.025+0.045 \mathrm{~g} \mathrm{ha}^{-1}\right)$; Moddus = trinexapac ethyl $\left(125 \mathrm{~g} \mathrm{ha}^{-1}\right) . \stackrel{2}{\prime}$ Means followed by the same letter, lower case on the vertical and capital case on the horizontal, do not differ among themselves by the Scott-Knott $(\mathrm{P}>0.05)$.

an elongation of the stem. However, this effect was more intense $(\mathrm{P}<0.05)$ when the growth regulator Stimulate was used than with the other compounds. The effect of crowding on the plant height was less intense $(\mathrm{P}<0.05)$ when the gibberellin synthesis inhibitors (Moddus and Pix) were used, compared to the other compounds or the untreated (Table 2).

Likewise, the ratio SM:RM was dependent on the density and growth regulator used (Table 3). Except for the plants treated with Moddus or Pix, all the other plants had increased shoot mass in relation to the root mass under conditions of elevated density per pot. Plants treated with the gibberellin synthesis inhibitors (Moddus and Pix) did not change the proportion shoot:root mass to the density (Table 3).

\section{Field experiments}

When compared to untreated plants, the gibberellin synthesis inhibitors reduced the proportion SM:RM in two experiments, whereas in the other three experiments no differences were detected. Corn plants and common beans in one experiment (Curitiba) were very responsive to gibberellin inhibitor, with a reduction of 34 and $39 \%$ on the S:R proportion, respectively (Table 4).

Another interesting fact is that the variability of the data (standard errors) was numerically reduced in four experiments, when the gibberellin synthesis inhibitors were used on the plants (Table 4). This result suggests an increased homogeneity of the crop plants when sprayed with the growth regulator.

One of the hypotheses of this work was that the plant morphology depended on the plant density per pot. Results from both group of experiments reported here support this idea. For instance, the total plant mass per plant has fitted well with the power equation for the species brown and common beans and cowpea (Table 1 and Figure 1). Likewise, both the plant height and the ratio SM:RM have increased with the plant density per pot in the untreated pots (Tables 2 and 3).

Other researchers have confirmed the effect of density on plant form. The most classical demonstration of this phenomenon was made by Yoda et al. (1963) who proposed that a power equation would explain the relationship between density and total individual mass. In fact, our data are in agreement with this observation, at least for the brown and common beans and cowpea (Table 1 and Figure 1).

One interpretation that we had for the similar lower asymptote for the brown and common beans and cowpea (Figure 1) is that, under the conditions tested, the carrying capacity per vessel is equivalent to $0.2 \mathrm{~g}$ per plant. We considered the conditions under these high densities to be very limiting to plant growth and probably they overrode all other physiological factors but plant survival. Therefore, for the growth regulator experiment we increased the pot size and limited the maximum density. Nevertheless, the hypothesis that different genotypes could differ in their ability to adjust to crowding was well proven when contrasting the regression coefficient for the equation between density and SM:RM (Table 1). At this moment, we are unsure as to how to interpret the fact that cowpea and peas had the smaller declivities and common beans and peas had the smallest regression coefficient (Table 1). We think all four genotypes tested may be less sensitive 
Table 3 - Ratio of the shoot mass:root mass from bean plants evaluated at 14 days after treatment with growth regulators. Pato Branco, Brazil

\begin{tabular}{|c|c|c|c|c|c|c|}
\hline Density & Untreated & TIBA $^{1 /}$ & Ethrel & Stimulate & Moddus & Pix \\
\hline 2 plant per pot & $2.13 \mathrm{bA}^{2 /}$ & $2.11 \mathrm{bA}$ & $2.15 \mathrm{bA}$ & $2.18 \mathrm{bA}$ & $2.15 \mathrm{aA}$ & $2.00 \mathrm{aA}$ \\
\hline 8 plant per pot & $2.68 \mathrm{aA}$ & $2.64 \mathrm{aA}$ & $2.73 \mathrm{aA}$ & $2.44 \mathrm{aB}$ & $2.15 \mathrm{aB}$ & $2.21 \mathrm{aB}$ \\
\hline
\end{tabular}

$\underline{1}$ Tiba $=2,3,5$-triiodobenzoic acid $\left(8 \mathrm{~g} \mathrm{ha}^{-1}\right)$; Ethrel $=$ etephon $\left(108 \mathrm{~g} \mathrm{ha}^{-1}\right)$; Pix = mepiquat chloride $\left(50 \mathrm{~g} \mathrm{ha}^{-1}\right)$; Stimulate $=3$-indolebutyric acid + kinetin + giberellic acid $\left(0.025+0.025+0.045 \mathrm{~g} \mathrm{ha}^{-1}\right)$; Moddus = trinexapac ethyl $\left(125 \mathrm{~g} \mathrm{ha}^{-1}\right) .{ }^{2 /}$ Means followed by the same letter, lower case on the vertical and capital case on the horizontal, do not differ among themselves by the Scott-Knott $(\mathrm{P}>0.05)$.

Table 4 - Shoot:Root proportion of three crops treated and untreated with gibberellin synthesis inhibitor evaluated 10 days after the application

\begin{tabular}{|l|c|c|}
\hline \multirow{2}{*}{\multicolumn{1}{|c|}{ Crop }} & \multicolumn{2}{|c|}{ Shoot:Root proportion } \\
\cline { 2 - 3 } & $\begin{array}{c}\text { No gibberellin } \\
\text { inhibitor }\end{array}$ & $\begin{array}{c}\text { With gibberellin } \\
\text { inhibitor }^{1 /}\end{array}$ \\
\hline Common bean CT $^{2 /}$ & $7.98 \pm 0.74^{3 /}$ & $4.84 \pm 0.28$ \\
\hline Common bean ES & $3.22 \pm 0.41$ & $3.35 \pm 0.41$ \\
\hline Corn CT & $0.88 \pm 0.08$ & $0.58 \pm 0.05$ \\
\hline Soybean CT & $2.40 \pm 0.29$ & $2.30 \pm 0.23$ \\
\hline Soybean RZ & $3.20 \pm 0.19$ & $3.33 \pm 0.12$ \\
\hline
\end{tabular}

1/ At Curitiba and Realeza = trinexapac ethyl $\left(125 \mathrm{~g} \mathrm{ha}^{-1}\right)$, and at Eldorado do Sul $=$ mepiquat chloride $\left(50 \mathrm{~g} \mathrm{ha}^{-1}\right) .{ }^{2 /} \mathrm{CT}=$ Curitiba, PR; ES = Eldorado do Sul, RS; RZ = Realeza, PR. ${ }^{3 /}$ Means followed by standard error.

to detect the light quality and the results suggests the azuki beans show high sensitivity to the change of light quality (crowding) (Table 1).

Our hypothesis that growth regulators could 'blind' the crop was tested using inhibitors of auxin synthesis (2,3,5-triiodobenzoic acid TIBA), inhibitors of gibberellin synthesis (trinexapac ethyl chloride - Moddus, and mepiquat chloride - Pix), ethylene precursor (etephon - Ethrel) and a plant growth stimulator (IBA + kinetin + GA3 - Stimulate). We decided not to include auxins (the herbicide 2,4-D) in the experiment because preliminary work has shown the rate that is needed to attain a positive response was very close to the rate that caused a toxic effect (Fleck et al., 1998). As expected from the known (Achard et al., 2007; Djakovic-Petrovic et al., 2007; Franklin, 2008; Ballare, 2009) signaling events involved in the INITIALISM, the gibberellin synthesis inhibitors (Moddus and Pix) were very effective in maintaining the SM:RM proportion at high plant densities (Table 3). Moreover, the shoot height of the $P$. vulgaris plants treated with these compounds had grown in a smaller degree when compared to the shoot growth of the plants sprayed with the other growth regulators (Table 2).

Under field conditions, gibberellin synthesis inhibitors either reduced or homogenized the plants, when compared to untreated crop plants (Table 4). Other researchers have also demonstrated that corn plants are very responsive to light quality (Afifi \& Swanton, 2011; Green-Tracewicz et al., 2012). We speculate that blinding the crop to initialism would be advantageous to the crop because it probably would avoid hierarchical differences among the plants and it would provide equal partition of environmental resources. However, specific experiments will need to be developed to demonstrate these hypotheses.

Our approach to initialism suggests two impacts on weed management. First, it emphasizes the importance of the preemergence herbicides to prevent the change in form and to guarantee the yield potential of the crop. Second, it is a completely different approach toward weed-competition tolerant crop. In fact, one conflicting hypothesis is that fast and tall growing crop plant would merely be tolerant to weed competition (Merotto Jr. et al., 2009). But such an approach did not produce a high yield producing crop and we assume INITIALISM-based morphogenesis is preventing the plant from achieving maximum productivity.

Overall, the results of this work, conducted under controlled conditions, suggest the possibility to neutralize the crop sensitivity to light quality or the existence of genotypes insensitive to light quality. Under field conditions and when post-emergence weed 
control is scheduled, the possible benefits of such a crop include tolerance to water limitation and high crop yield due to a long root system since the beginning of the life cycle of the crop plants. For rangeland conditions, additional benefits could be forecasted, such as: increased pasture tolerance to cattle trampling and increased tolerant to competition for pasture plants from different species when grown in intercropping. Finally, another possible benefit of the initialism theory is that the light quality itself or the genes/proteins involved in its response could be used as indicators of crop response to weeds and may indicate the best time to use weed control tactics (Merotto Jr. et al., 2009). However, the authors would like to point out that all these possible benefits have not been tested at this moment.

The plant density affects its morphology. Crowding treatments, within limits, were appropriated to test the initialism effect. Among the six Fabaceae species, the plant sensitivity to crowding conditions depended on the genotype tested. Plant growth regulators affect the initialism effect. Gibberellin synthesis inhibitors were efficient in maintaining the shoot to root proportion of common bean (Phaseolus vulgaris) plants under crowding conditions. In the field, gibberellin synthesis inhibitors either reduced or homogenized the shoot to the root proportion of three crop species.

\section{ACKNOWLEDGEMENTS}

We would like to thank D. B. Schramm, D. Brand, and L. B. Costa for the help they provided with the experiment at UFRGS. We thank F. Patel, E. Xavier, F. Debastiani, and E. Miotto Jr. for their help with the experiment at UTFPR. We also thank S. A. Jele Jr. for the help provided with the experiments at PUC. CNPq (Brazilian Research Council), CAPES (Brazilian Graduate School Council), Fundação Araucária, PUC-Curitiba, UTFPR, and UFRGS are gratefully acknowledged for their financial support. We also would like to thank Dr. Pascal Marnotte (CIRAD, France) and Dr. Nelson Kruse (UFSM, Brazil) for their helpful suggestions on an early draft of this paper.

\section{LITERATURE CITED}

ACHARD, P. et al. DELLAs contribute to plant photomorphogenesis. Plant Physiol., v. 143, n. 3, p. 1163-1172, 2007.

AFIFI, M.; SWANTON, C. J. Maize seed and stem roots differ in response to neighbouring weeds. Weed Res., v. 51, n. 5, p. 442-450, 2011.

ALMEIDA M. L.; MUNDSTOCK, C. M. O afilhamento de aveia é afetado pela qualidade da luz em plantas sob competição. Ci. Rural, v. 31, n. 3, p. 393-400, 2001.

BALLARE, C. L. Illuminated behaviour: phytochrome as a key regulator of light foraging and plant anti-herbivore defence. Plant Cell Environ., v. 32, n. 6, p. 713-725, 2009.

BOCCALANDRO, H. E. et al. Increased phytochrome B alleviates density effects on tuber yield of field potato crops. Plant Physiol., v. 133, n. 4, p. 1539-1546, 2003.

BURKHOLDER, P. R. Cooperation and conflict among primitive organisms. Am. Sci., v. 40, n. 4, p. 601-631, 1952.

DJAKOVIC-PETROVIC, T. et al. DELLA protein function in growth responses to canopy signals. Plant J., v. 51, n. 1, p. 117-126, 2007.

FLECK, N. G. et al. Avaliação de subdoses de herbicidas sistêmicos não-seletivos em soja. Pesq. Agropec. Gaúcha, v. 4, n. 2, p. 151-156, 1998.

FRANKLIN, K. A. Shade avoidance. New Phytol., v. 179, n. 4, p. 930-944, 2008.

GREEN-TRACEWICZ, E.; PAGE, E. R.; SWANTON, C. J. Light quality and the critical period for weed control in soybean. Weed Sci., v. 60, n. 1, p. 86-91, 2012.

MALIAKAL, S. et al. Effects of red to far-red ratio and density on biomass allocation and gas exchange in Impatiens capensis. Intern. J. Plant Sci., v. 160, n. 4, p. 723-733, 1999.

MEROTTO JR., A. et al. Perspectives for using light quality knowledge as an advanced ecophysiological weed management tool. Planta Daninha, v. 27, n. 2, p. 407-419, 2009.

RAJCAN I.; SWANTON C. L. Understanding maize-weed competition - resource competition, light quality and the whole plant. Field Crops Res., v. 71, n. 2, p. 139-150, 2001.

VIDAL, R. A. et al. Initialism: a new term to describe the first mechanism of negative interaction between weeds and crops. J. Plant Dis. Protec., v. 21, n. 1, p. 95-98, 2008.

YODA, K. T. et al. Self-thinning in overcrowded pure stands under cultivated and natural conditions. J. Biol. Osaka City Univer., v. 14, n. 1, p. 107-129, 1963.

Planta Daninha, Viçosa-MG, v. 30, n. 3, p. 469-475, 2012 